\title{
Simulating climatic mass balance, seasonal snow development and associated freshwater runoff in the Kongsfjord basin, Svalbard (1980-2016)
}

\author{
ANKIT PRAMANIK, ${ }^{1,2,3}$ WARD VAN PELT, ${ }^{4}$ JACK KOHLER, ${ }^{1}$ THOMAS V. SCHULER ${ }^{2,5}$ \\ ${ }^{1}$ Norwegian Polar Institute; Fram Centre, Tromsø, Norway \\ ${ }^{2}$ Department of Geosciences, University of Oslo, Oslo, Norway \\ ${ }^{3}$ ESSO-National Centre for Antarctic and Ocean Research, Ministry of Earth Sciences, Goa, India \\ ${ }^{4}$ Department of Earth Sciences, Uppsala University, Uppsala, Sweden \\ ${ }^{5}$ Department of Arctic Geophysics, University Center in Svalbard, Longyearbyen, Norway \\ Correspondence: Ankit Pramanik<ankit@ncaor.gov.in>
}

\begin{abstract}
The Kongsfjord basin in northwest Svalbard is the site of a number of interdisciplinary studies concerned with the effect of fresh water from seasonal snow and glacier melt on the physical and biological environment. We use an energy-balance model coupled with a subsurface snow model to simulate the long-term climatic mass-balance evolution of the glaciers and the seasonal snow development of nonglacierized parts of the Kongsfjord basin. Runoff from both glacierized and nonglacierized parts of the basin is simulated to quantify the fresh water flux to the fjord. The model is calibrated with long-term mass-balance data measured at four glaciers, and with automatic weather station data. The simulated area-averaged climatic mass balance for the whole basin is positive $\left(+0.23 \mathrm{~m}\right.$ w.e. $\left.\mathrm{a}^{-1}\right)$ over the period 1980-2016; however, the trend for net mass balance is not statistically significant over the simulation period, despite the observed ongoing summer warming. Refreezing equals $0.24 \mathrm{~m}$ w.e. $\mathrm{a}^{-1}$, which is equivalent to $17 \%$ of the total mass gain from precipitation and moisture deposition. Total runoff comprises contributions from seasonal snow in the nonglacierized area $(16 \%)$ and glacier discharge $(84 \%)$. Model time series shows a significant increasing trend for annual glacier runoff $(6.83 \times$ $10^{6} \mathrm{~m}^{3} \mathrm{a}^{-1}$ ) over the simulation period.
\end{abstract}

KEYWORDS: energy balance, glacier discharge, glacier mass balance, glacier modelling

\section{INTRODUCTION}

In the currently warming climate, meltwater runoff from glaciers and ice caps, especially in the Arctic, is a major contributor to sea-level rise (Church and others, 2011; Jacob and others, 2012; Machguth and others, 2013; Mernild and others, 2014; Moon and others, 2018). It is expected that glaciers and ice caps will lead to $81 \pm 43 \mathrm{~mm}$ of sea-level rise by 2050, assuming current acceleration (Meier and others, 2007; Radic and Hock, 2011; IPCC, 2013). The Arctic is experiencing greater warming than the global average through feedbacks caused by changes in sea-ice extent, surface reflectivity and air temperature, a process known as the 'Arctic amplification' (Manabe and Stouffer, 1980; Serreze and Francis, 2006; Serreze and others, 2009).

The High Arctic archipelago Svalbard has a glacierized area of $\sim 34000 \mathrm{~km}^{2}$ (Nuth and others, 2013), equivalent to $5 \%$ of the world's land-ice mass outside of Greenland and Antarctica (Pfeffer and others, 2014; Aas and others, 2016). Glaciers cover $\sim 60 \%$ of the land area of Svalbard (Hagen and others, 2003) and, if melted, could potentially contribute 14-26 mm to global sea-level rise (Radic and Hock, 2010; Huss and Farinotti, 2012; Martín-Español and others, 2015). Mean annual temperature in Longyearbyen has increased by $0.25 \mathrm{~K}$ decade ${ }^{-1}$ over the past 100 years (Førland and others, 2011), with most of the warming in the more recent period, since $1975\left(\sim 1.0 \mathrm{~K} \mathrm{decade}^{-1}\right)$; the strongest recorded warming in Europe (Førland and others,
2011; Nordli and others, 2014). The recent warming is most pronounced in winter and spring and temperatures are expected to continue to increase in the 21st century (IPCC, 2013). Simultaneously, over the period 1964-97, precipitation in Longyearbyen has increased by $1.7 \%$ decade $^{-1}$ (Førland and Hanssen-Bauer, 2000). In terms of glacier mass balance, however, this weak increase is not enough to compensate for effects of the warming. Svalbard glaciers show a declining mass-balance trend since 1967, when the first glaciological measurements were started (WGMS, 2017; Østby and others, 2017).

In northwest Svalbard, the Kongsfjord basin near $\mathrm{Ny}$ Ålesund plays a crucial role in scientific research in oceanography, meteorology, biology, ecology and land surface processes (hydrology, glaciology). In Kongsfjord, there are glaciers of different shapes and sizes and with different dynamic behaviour (Liestøl, 1988; Hagen and others, 1993). Studying mass balance of these glaciers is important for understanding the present trend of glacier retreat as well as to quantify fresh water discharge to the fjord. Apart from glacier runoff, another significant source of fresh water to the fjord in this region is meltwater from seasonal snow in the nonglacierized area. Freshwater runoff at the base of tidewater glaciers creates a buoyant plume when entering the fjord (Cowton and others, 2015; How and others, 2017) and mixes with the fjord water at different vertical depth affecting the fjord's circulation (Sundfjord and others, 
2017). Plumes bring nutrients and plankton to the fjord surface, propagating their impact through the food chain to a wide range of species, and thus plays a crucial role in the fjord ecosystem (Lydersen and others, 2014). Accurately quantifying the spatial and temporal distributions of meltwater runoff is, therefore, crucial for understanding the fjord system. Insight into runoff can only be gained through distributed modelling; Kongsfjord is particularly well suited for this task since long-term records (the longest in Svalbard) of glacier data exist for model calibration and validation.

Models have been widely used to simulate mass balance of glaciers from regional to global scales ranging in complexity from conceptual degree day models (Hock, 2003; Nuth and others, 2012) to physically-based energy-balance models (Hock, 2005; Arnold and others, 2006). Energybalance models consider all the energy fluxes interacting with the glacier surface to compute surface temperatures $T_{\mathrm{S}}$; the energy equivalent of $T_{\mathrm{S}}>0{ }^{\circ} \mathrm{C}$ is used to calculate melt at the glacier surface. Meltwater percolates through the snowpack and may refreeze, depending on the subsurface temperature; any excess meltwater contributes to runoff. Refreezing plays a crucial role in the mass budget of Arctic glaciers as it increases the temperature and density of the snowpack, and reduces and delays mass loss through runoff (Wright and others, 2007; Reijmer and others, 2012). Furthermore, heat released by refreezing has a major impact on the thermal structure of a glacier (Poinar and others, 2017). Refreezing below the previous year's summer surface in the firn area is known as internal accumulation (Schneider and Jansson, 2004), which is not captured by conventional mass-balance monitoring. In contrast to non-polar regions, refreezing strongly affects the mass balance of High Arctic glaciers, mainly due to the strong seasonal temperature cycle (Bliss and others, 2014). Very cold winters with relatively little or no insolation lead to cold snowpacks, increasing the potential for refreezing of percolated meltwater during the melt season and storage of water in the snow or firn after the melt season.

Previous modelling studies of mass balance in the Kongsfjord region mainly focused on four glaciers: Austre Brøggerbreen (BRB), Midtre Lovénbreen (MLB), Kongsvegen (KNG) and Kronebreen-Holtedahlfonna (HDF) (Table 1). All of these studies have focused on either single glaciers (Bruland \& Hagen, 2002) or partial areas of Kongsfjord (Lefauconnier and others, 1994a; Kohler and others, 2007; Rasmussen and Kohler, 2007; Nuth and others, 2012; Van Pelt and Kohler, 2015). In this study, meltwater production is simulated considering all glaciers in the Kongsfjord basin, and additionally, we simulate seasonal snow in the nonglacierized area. This enables us to distinguish runoff contributions to the fjord from glaciers and land. Glacier and seasonal snow runoff modelling over entire catchments is required to estimate the total water budget, as has been done in several glacierized catchments in the world (e.g. Himalaya, Alps, Central Asia, Alaska, Andes) (Verbunt and others, 2003; Jeelani and others, 2012; Duethmann and others, 2015; Bring and others, 2016; Mernild and others, 2016; Valentin and others, 2018). The long-term simulation allows us to detect trends in seasonal snow amounts and the climatic mass balance $(\mathrm{CMB})$ and its components, and relate them to transient climate conditions. We estimate and analyze the long-term CMB evolution of the entire glacierized area of Kongsfjord basin, and quantify runoff into the fjord from glaciers and from the seasonal snow of the nonglacierized area. Simulations are performed with a surface energy balance - firn model (Van Pelt and Kohler, 2015), which has been extended with a soil model (Westermann and others, 2011) to simulate seasonal snow in nonglacierized parts of the domain.

\section{STUDY AREA}

Kongsfjord is open to the sea to the west and is surrounded by glaciers to the south, east, and north (Fig. 1). The glaciers to the south are small land-terminating glaciers (average area per glacier $\sim 6.5 \mathrm{~km}^{2}$ ), whereas the glaciers to the east and north are mainly large tidewater glaciers $\left(>50 \mathrm{~km}^{2}\right)$. The total nonglacierized area (tundra, hills, and nunataks) amounts to $293 \mathrm{~km}^{2}$ and accounts for $20 \%$ of the Kongsfjord basin $\left(\sim 1440 \mathrm{~km}^{2}\right)$.

In this study, we divide the glacierized area of Kongsfjord basin into three subregions; south $\left(\sim 42 \mathrm{~km}^{2}\right)$, east $\left(\sim 573 \mathrm{~km}^{2}\right)$ and north $\left(\sim 533 \mathrm{~km}^{2}\right)$ (Figs 1, 2). Glaciers in south region are all land-terminating, low-lying and relatively slow moving (Hagen and others, 1993). The east region contains two large tidewater glacier systems; Kongsvegen-Sidevegen and Kronebreen, the latter draining the ice fields of Holtedahlfonna (HDF) and Infantfonna. KNG is a surgetype glacier currently in its quiescent phase, flowing at low velocities (2-8 $\mathrm{m} \mathrm{a}^{-1}$ ) and undergoing surface steepening (Hagen and others, 1999; Kohler and others, 2007; Nuth and others, 2012). Kronebreen (KRB), which shares its terminus with KNG, is a fast-flowing tidewater glacier (300$800 \mathrm{~m} \mathrm{a}^{-1}$; Kääb and others, 2005). It has experienced two periods of rapid frontal retreat, $\sim 3 \mathrm{~km}$ between 1966 and 1980, and $\sim 1 \mathrm{~km}$ between 2011 and 2013 (Nuth and others, 2012, 2013); this most recent retreat is still ongoing.

Table 1. Previous mass-balance studies on four glaciers of Kongsfjord basin

\begin{tabular}{|c|c|c|c|c|}
\hline Glacier & Study year & CMB (m w.e. $\left.\mathrm{a}^{-1}\right)$ & Method & Study \\
\hline \multirow[t]{3}{*}{ Austre Brøggerbreen (BRB) } & $1912-88$ & -0.45 & Simple statistical model & Lefauconnier and Hagen (1990) \\
\hline & $1971-99$ & -0.69 & Precipitation-runoff model & Bruland and Hagen (2002) \\
\hline & 1948-2005 & -0.41 & Upper-air meteorological model & Rasmussen and Kohler (2007) \\
\hline Midtre Lovénbreen (MLB) & 1948-2005 & -0.31 & Upper-air meteorological model & Rasmussen and Kohler (2007) \\
\hline \multirow[t]{3}{*}{ Kongsvegen (KNG) } & 1967-90 & -0.11 & Ice-coring and radioactive layering & Lefauconnier and others (1994a) \\
\hline & 1948-2005 & +0.03 & Upper-air meteorological model & Rasmussen and Kohler (2007) \\
\hline & $1961-2012$ & +0.01 & Coupled energy-balance- snow model & Van Pelt and Kohler (2015) \\
\hline \multirow[t]{2}{*}{ Holtedahlfonna (HDF) } & 1969-2007 & -0.02 & Degree-day model & Nuth and Others (2012) \\
\hline & 1961-2012 & +0.13 & Coupled energy-balance- snow model & Van Pelt and Kohler (2015) \\
\hline
\end{tabular}




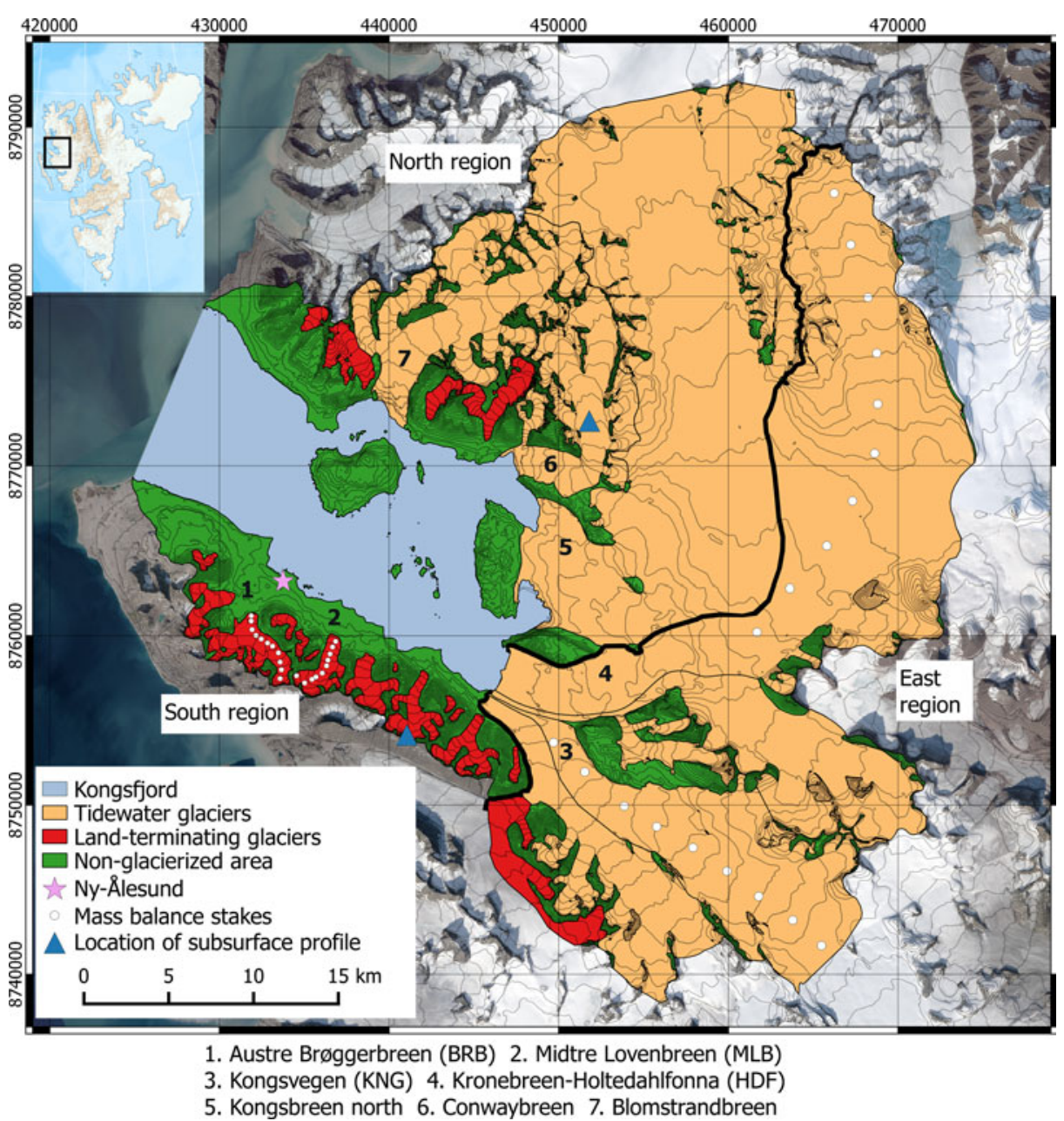

Fig. 1. Kongsfjord basin; Orange colour indicates tidewater glaciers, red colour indicates land-terminating glaciers, and green colour indicates non-glacierized area. Individual glaciers are shown with the thin black line. Thick black lines divide east region from south region and north region from east region. Mass-balance stakes of the four mass balance glaciers are shown with white dots. Ny-Ålesund is shown with magenta star. Blue triangles indicate the locations (elevation $610 \mathrm{~m}$ a.s.l.) where subsurface density has been investigated. The background is Landsat mosaic image.

The north region of the basin contains three tidewater glaciers (Blomstrandbreen, Conwaybreen and Kongsbreen, from west to east) and a few smaller land-terminating glaciers (Hagen and others, 1993). The tidewater glaciers in this area vary in their dynamic behaviour and contribute substantial mass to the fjord through calving (Liestøl, 1988; Lefauconnier and others, 1994b). Blomstrandbreen surged in 2007 (Sund and Eiken, 2010; Mansell and others, 2012; Burton and others, 2016). Kongsbreen North was observed to move at $\sim 2.8 \mathrm{~m} \mathrm{~d}^{-1}$ in autumn 2012 (Schellenberger and others, 2015).

A meteorological station is situated on the southwest side of the fjord at $\mathrm{Ny}$-Ålesund $\left(78.92^{\circ} \mathrm{N}, 11.91^{\circ} \mathrm{E}\right)$. We use observational data from four glaciers (Fig. 1) (Kohler, 2013) monitored by the Norwegian Polar Institute (NPI) to calibrate and validate the model; two tidewater glaciers, HDF and $\mathrm{KNG}$, and two land-terminating glaciers, BRB and MLB.

\section{DATA}

\subsection{Surface DEM and glacier mask}

We use a Digital Elevation Model (DEM) with a $5 \mathrm{~m}$ horizontal resolution, constructed by the NPI from aerial surveys in
2009 and 2010 (NPI, 2014), averaging values onto a 250 $\mathrm{m} \times 250 \mathrm{~m}$ model grid. A recent model grid and the most recent glacier mask (König and others, 2014) is used throughout the study period. Elevation and glacier outlines are assumed to be constant throughout the simulation period.

\subsection{Meteorological input}

To force the model, we use 6 hourly weather station data from $\mathrm{Ny}$-Ålesund (air temperature, air pressure, cloud cover and relative humidity), and downscaled precipitation data derived from the ERA-Interim re-analysis of the European Center for Medium-Range Weather Forecast (Dee and others, 2011). Pressure, cloudiness and humidity records from $\mathrm{Ny}$-Ålesund are extrapolated to the model grid using fixed lapse rates, extracted from HIRLAM regional climate model output used in Van Pelt and Kohler (2015). In this work, the temperature lapse rate (TLR) is an adjustable parameter, the calibration of which is discussed in section 4.2. Precipitation from ERA-Interim is available from 1979 at 6-h intervals and at $\sim 80 \mathrm{~km}$ horizontal resolution (Dee and others, 2011). Østby and others (2017) downscaled this product to $1 \mathrm{~km}$ resolution over Svalbard using the linear theory of orographic precipitation (Smith and Barstad, 


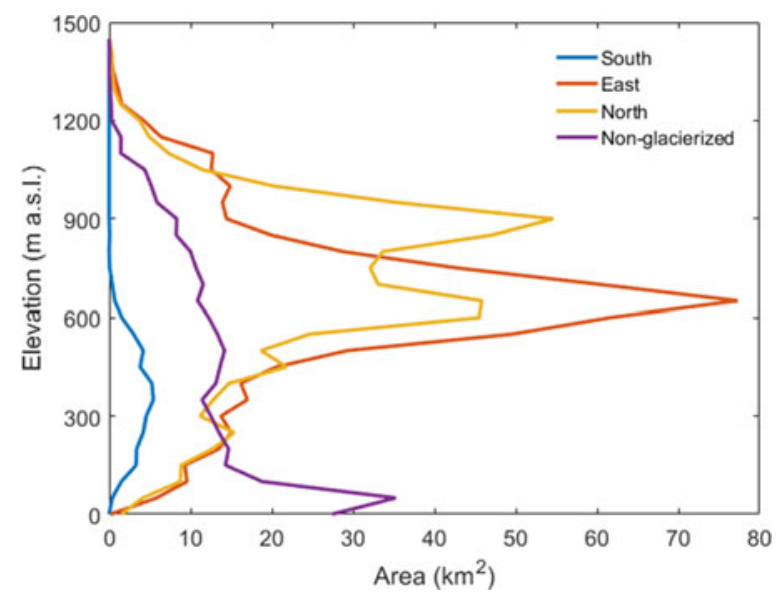

Fig. 2. Regional hypsometries of three regions. Elevation interval is $50 \mathrm{~m}$. Maximum elevation is $1417 \mathrm{~m}$ a.s.l.

2004). In this study, we re-grid the $1 \mathrm{~km}$ product to our model domain by linear interpolation and apply a spatial linear correction derived from the measured winter mass balance, to reduce the biases of ERA-Interim precipitation.

\subsection{Stake and glacier-wide mass balance}

Mass-balance measurements of the two land-terminating glaciers BRB and MLB started in 1967 and 1968, respectively, while monitoring of KNG and HDF started in 1987 and 2004, respectively (WGMS, 2017). Seasonal mass balance is measured using stakes drilled into firn/ice along the glacier centrelines (Fig. 1). Stakes are measured twice a year in April and September to yield winter $\left(b_{\mathrm{w}}\right)$ and summer $\left(b_{\mathrm{s}}\right)$ balances. These point measurements (henceforth referred to as stake balances) are then extrapolated using the glacier hypsometry to calculate glacier-wide winter $\left(B_{\mathrm{w}}\right)$, summer $\left(B_{\mathrm{s}}\right)$ and net $\left(B_{\mathrm{n}}\right)$ mass balances, assuming a functional relationship between mass balance and elevation. We use stake balances (winter and summer) for calibration of climate parameters of the model (section 4.2).

\section{MODEL AND SET UP}

\subsection{Model description}

The model employed in this study simulates mass and energy exchange between atmosphere, surface and the underlying snow, firn and /or ice and it has been used previously by Van Pelt and Kohler (2015) for the glacier system KNG and HDF. Here, we use a different precipitation product for forcing and add a separate subsurface scheme for the nonglacierized part of the domain to expand the application to the entire Kongsfjord basin.

The model iteratively solves the energy-balance equation for each time step to calculate the surface temperature. The surface temperature is capped at the melting point and excess energy is used to melt the surface. The meltwater enters the subsurface snow/firn pack and serves as input to the subsurface module.

The subsurface module is an update (Reijmer and Hock, 2008) of the SOMARS model (Simulation Of glacier Mass balance And Related Subsurface processes; Greuell and Konzelmann (1994)), which simulates the evolution of vertical profiles of temperature, density and water content and which has been repeatedly applied on Svalbard (Van Pelt and others, 2012, 2014, 2016b; Østby and others, 2013; Østby and others, 2017). Briefly, percolated meltwater refreezes, depending on the subsurface temperature and density of snowpack in each layer and excess meltwater, if any, is routed vertically according to a tipping-bucket scheme. As percolated meltwater refreezes, it releases latent heat, which increases the temperature of the snowpack. Apart from gravitational densification, refrozen meltwater increases the density of the snowpack. Runoff occurs at the firn/ice transition in case a snowpack is present or at the surface in case of bare-ice exposure. The model does not consider any horizontal transport of water in between grid cells since it requires explicit treatment of surface and subsurface drainage, which is beyond the scope of the study. The subsurface model comprises a vertically adjustable grid of 100 layers, the thickness of which increases with depths by merging the 15th, 30th and 45th layers, and which vary from $0.1 \mathrm{~m}$ to $0.8 \mathrm{~m}$. For the nonglacierized area, a subsurface soil model (Westermann and others, 2011) connected with the energy-balance model simulates the heat conduction in the soil below the snowpack.

The $\mathrm{CMB}$ is the sum of the mass gain due to precipitation, riming at the surface and mass loss due to runoff, sublimation or evaporation. The winter balance refers to the period between 1 September of the previous year and 15 April of the current year, while summer balance corresponds to the period between 16 April and 31 August. The net balance is calculated as the sum of the winter and summer balances i.e. it covers the period between 1 September of the previous year and 31 August of the present year. Annual melt, refreezing and runoff are also calculated over the same period.

\subsection{Calibration of parameters}

Van Pelt and Kohler (2015) calibrated parameters determining incoming shortwave and longwave radiation, turbulent exchange coefficient and the albedos of snow and firn. Here, we adopt their parameter values without further refinement but calibrate TLR to achieve optimal agreement between modelled and measured stake summer balances at four glaciers (BRB, MLB, KNG and HDF; Fig. 3) by minimizing the RMSE value. Model calibration experiments are run over the observation period at selected grid points where observational data exist. Table 2 presents the calibrated parameter values used for the model application to the whole domain. We used similar TLRs for glaciers close to their respective calibrating glaciers, i.e. we use the HDF TLR for the glaciers in the north and the MLB TLR for the south side of the fjord. Time series of glacier-wide winter $\left(B_{\mathrm{w}}\right)$, summer $\left(B_{\mathrm{s}}\right)$ and net balance $\left(B_{\mathrm{n}}\right)$ of the four mass-balance glaciers BRB, MLB, KNG and HDF (Figs 4a-d) demonstrate that the model reproduces year to year variability of mass balance very well, thus giving confidence in the interannual variability of precipitation forcing and TLR calibration.

\subsection{Initialization}

An initialization run is performed to generate suitable subsurface conditions (temperature, density and water content) for the start of the simulation in 1979. At the start of the initialization, the density corresponds to that of ice $\left(900 \mathrm{~kg} \mathrm{~m}^{-3}\right)$, with a constant temperature of $270 \mathrm{~K}$ and zero water content. We perform 40 years of initialization in two steps, first running 

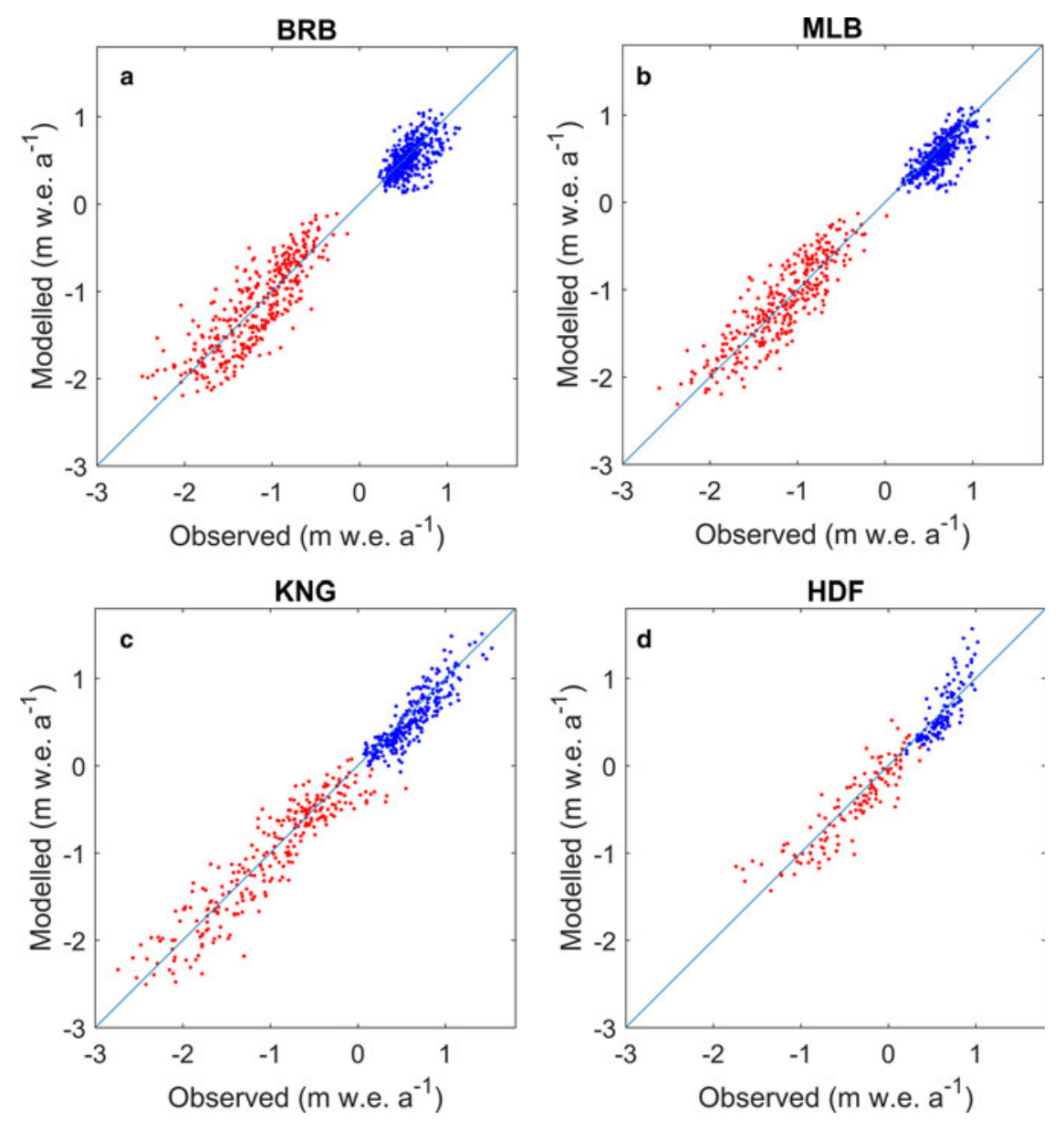

Fig. 3. Best match of modelled and measured stake winter ( $b_{\mathrm{w}}$, blue) and summer ( $b_{\mathrm{s}}$, Red) balance for all four mass balance glaciers (a) Austre Brøggerbreen (BRB), (b) Midtre Lovénbreen (MLB), (c) Kongsvegen (KNG) and (d) Holtedahlfonna (HDF) after calibration.

the model from 1979 to 1999 and then starting the second iteration from the final state of the first iteration over the same period.

\section{RESULTS AND DISCUSSION}

\subsection{Climatic mass balance}

The area-averaged climatic mass balance, snowfall, rainfall, melt, refreezing and runoff over the period 1980-2016 for the entire glacierized basin and the three subregions are shown in Table 3. Figure 5 shows spatial distributions of precipitation, melt, refreezing and climatic mass balance. Glaciers on the south and east sides of the fjord receive less snowfall compared with the glaciers in the north, while overall melt rates are highest in the south. The modelled mean $\mathrm{CMB}$ of glacierized area of Kongsfjord is positive $\left(+0.23 \mathrm{~m}\right.$ w.e. $\left.\mathrm{a}^{-1}\right)$ for the period $1980-2016$. The CMB varies considerably between regions, however, with a strongly negative $\mathrm{CMB}$ in the south $\left(-0.43 \mathrm{~m}\right.$ w.e. $\left.\mathrm{a}^{-1}\right)$, a weakly negative mass balance in the east $\left(-0.08 \mathrm{~m}\right.$ w.e. $\left.\mathrm{a}^{-1}\right)$ and positive mass balance in the north $\left(+0.61 \mathrm{~m}\right.$ w.e. $\left.\mathrm{a}^{-1}\right)$. We found glacier-wide mass losses for the (land-terminating) glaciers on the south side, in agreement with the observed retreat (Rippin and others, 2003; Kohler and others, 2018). Glaciers in the north are at higher elevations, and experience on average 56\% more snowfall and 59\% less melt compared with glaciers in the south region. Glaciers in the north and east are mostly tidewater glaciers and lose mass due to calving. For HDF, calving rates at its tidewater terminus KRB have previously been estimated at $-0.42 \pm 0.10 \mathrm{~m}$ w.e. $\mathrm{a}^{-1}$ for $1966-$ 2007 (Nuth and others, 2012), which suggests that the total

Table 2. Calibrated temperature lapse rates for mass-balance glaciers. Bias is defined as mean difference between modelled and measured mass balance

\begin{tabular}{|c|c|c|c|c|c|}
\hline \multirow[t]{2}{*}{ Glacier } & \multirow{2}{*}{$\begin{array}{c}\text { Temperature } \\
\text { lapse rate }\left(\mathrm{km}^{-1}\right)\end{array}$} & \multicolumn{2}{|c|}{ Summer Balance (m w.e. $\mathrm{a}^{-1}$ ) } & \multicolumn{2}{|c|}{ Winter balance ( $\mathrm{m}$ w.e. $\mathrm{a}^{-1}$ ) } \\
\hline & & RMSE & Bias & RMSE & Bias \\
\hline Austre Brøggerbreen & 3.2 & 0.29 & 0.00 & 0.17 & -0.04 \\
\hline Midtre Lovénbreen & 3.2 & 0.25 & 0.02 & 0.17 & -0.07 \\
\hline Kongsvegen & 3.8 & 0.26 & -0.04 & 0.17 & -0.08 \\
\hline Holtedahlfonna & 4.2 & 0.22 & -0.04 & 0.18 & -0.01 \\
\hline
\end{tabular}



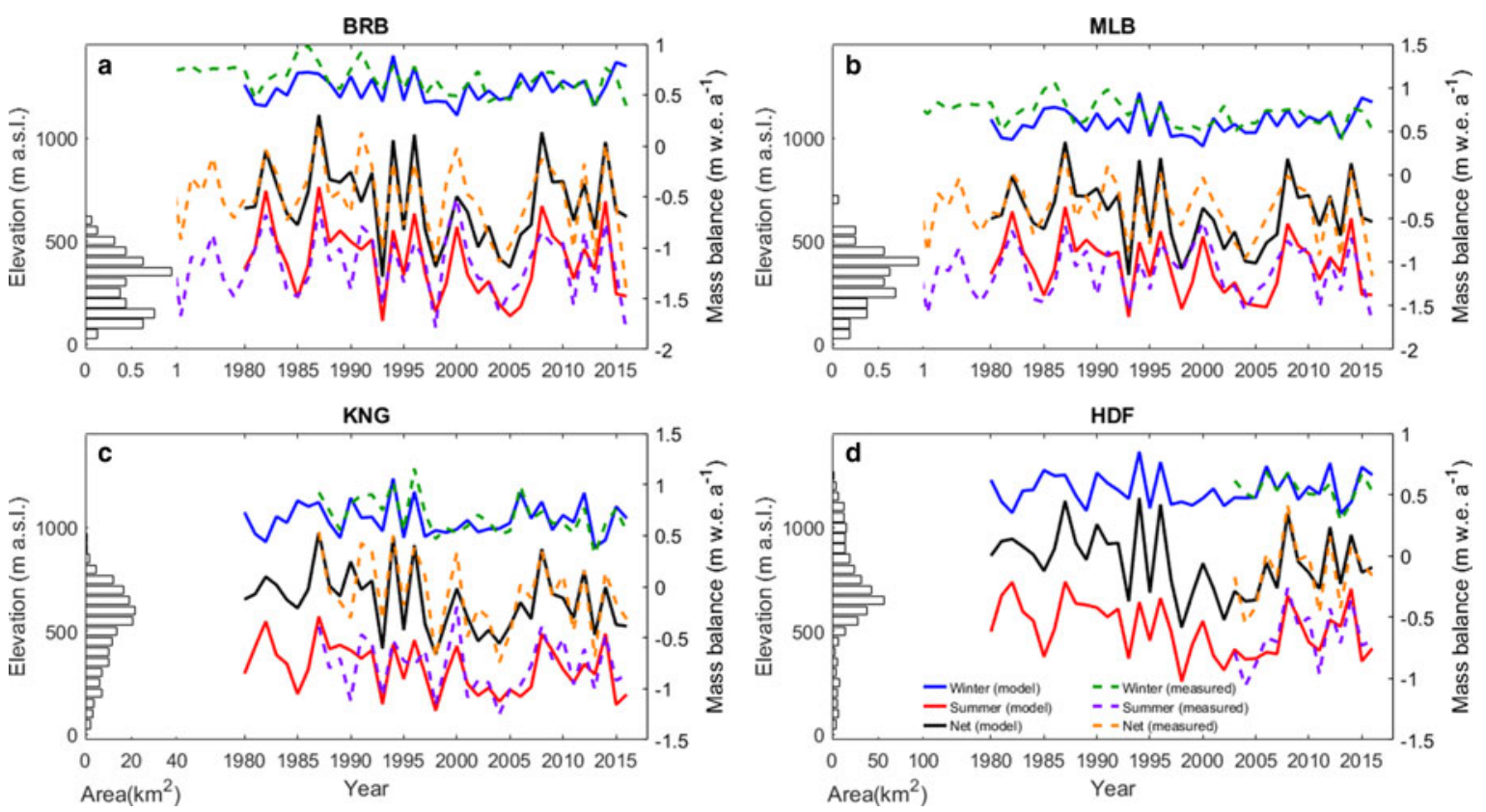

Fig. 4. Modelled (solid line) and measured (dashed line) winter $\left(B_{\mathrm{w}}\right)$, summer $\left(B_{\mathrm{s}}\right)$ and net $\left(B_{\mathrm{n}}\right)$ mass balances of (a) Austre Brøggerbreen (BRB), (b) Midtre Lovénbreen (MLB), (c) Kongsvegen (KNG) and (d) Holtedahlfonna (HDF) (right axis). The left-hand side of each panel shows the hypsometry of the respective glacier (left axis).

mass balance is much more negative than the simulated $\mathrm{CMB}$ of $-0.05 \pm 0.26 \mathrm{~m}$ w.e. $\mathrm{a}^{-1}$ for $1980-2016$.

Overall, refreezing comprises $17 \%$ of the total accumulation from precipitation and moisture deposition for the entire glacierized part of the basin. Average refreezing amounts to $0.24 \mathrm{~m}$ w.e. $\mathrm{a}^{-1}$ and consists of similar contributions of refreezing of percolating water $\left(0.12 \mathrm{~m}\right.$ w.e. $\left.\mathrm{a}^{-1}\right)$ in spring/ summer and refreezing of stored irreducible and slush water $\left(0.12 \mathrm{~m}\right.$ w.e. $\left.\mathrm{a}^{-1}\right)$ in winter. For comparison, a mean value for total refreezing of $0.30 \mathrm{~m}$ w.e. $\mathrm{a}^{-1}$ was found on HDF and KNG by Van Pelt and Kohler (2015). Refreezing varies spatially, with lower values in the south $(0.21 \mathrm{~m} \mathrm{w}$. e. $\left.\mathrm{a}^{-1}\right)$ than the north region $\left(0.27 \mathrm{~m}\right.$ w.e. $\left.\mathrm{a}^{-1}\right)$. The higher refreezing rates in the north region are most likely due to the relatively larger accumulation zones that allow deeper water storage in firn and refreezing in the winter season. Substantial refreezing also occurs in seasonal snow on soil $\left(0.21 \mathrm{~m}\right.$ w.e. $\left.\mathrm{a}^{-1}\right)$, most of which is related to rainfall events during the cold season. Major refreezing events after heavy rainfall during the core winter season can cause the formation of basal ice in the snowpack (Hansen and others, 2014; Van Pelt and others, 2016a, 2016b), which can dramatically impact food supplies of grazing herbivores in Svalbard (Kohler and Aanes, 2004).

Time series of annual climatic mass balance, snowfall, rain, melt and refreezing are shown in Fig. 6 for the entire glacierized area and for the three subregions. The area-averaged net balance has a weakly negative but nonsignificant trend for the entire glacierized basin and the south and north regions over the simulation period, whereas the trend is significant for the east region (Table 4). Summer balance has a weakly negative but significant trend for the entire glacierized area, east and north region, while the trend in the south region is nonsignificant over the simulation period 1980-2016 (Table 4).

We find an increasing trend of $0.12 \mathrm{~K} \mathrm{a}^{-1}, 0.04 \mathrm{~K} \mathrm{a}^{-1}$ and $0.09 \mathrm{~K} \mathrm{a}^{-1}$ (with $p<0.005$ for all) for mean winter, summer and annual temperatures respectively (Fig. 7) over the simulation period 1980-2016. We find correlations of -0.32 $(p<0.06)$ and $0.77(p<0.01)$ between net mass balance and mean summer temperature, and between net mass balance and annual snowfall, respectively, for the entire glacierized area. Net mass balance has a significant correlation to the annual snowfall for the south, east and north regions, with the strongest correlation observed in the latter region (Table 5). The anticorrelation of net mass balance with mean summer temperature is weakest and nonsignificant for north region, however, the anticorrelation is stronger in the east and south regions (Table 5), which indicates that mass balance of glaciers in the south and east is more sensitive to temperature than in the north. Winter precipitation shows a positive but nonsignificant trend for the entire

Table 3. Area-averaged glacier wide climatic mass balance $\left(B_{\mathrm{w}}, B_{\mathrm{s}}, B_{\mathrm{n}}\right)$, melt, refreezing and runoff for three regions and entire glacierized area, 1980-2016

Area averaged (1980-2016): $\mathrm{m}$ w.e. $\mathrm{a}^{-1}$

\begin{tabular}{|c|c|c|c|c|c|c|c|c|}
\hline & $B_{\mathrm{w}}$ & $B_{\mathrm{s}}$ & $B_{\mathrm{n}}$ & Snowfall & Rain & Melt & Refreezing & Runoff \\
\hline All Glaciers & 0.73 & -0.50 & 0.23 & 0.99 & 0.19 & 1.01 & 0.24 & 0.97 \\
\hline South & 0.58 & -1.01 & -0.43 & 0.80 & 0.30 & 1.46 & 0.21 & 1.55 \\
\hline East & 0.58 & -0.66 & -0.08 & 0.77 & 0.15 & 1.07 & 0.22 & 1.00 \\
\hline North & 0.89 & -0.28 & 0.61 & 1.25 & 0.23 & 0.92 & 0.27 & 0.88 \\
\hline
\end{tabular}



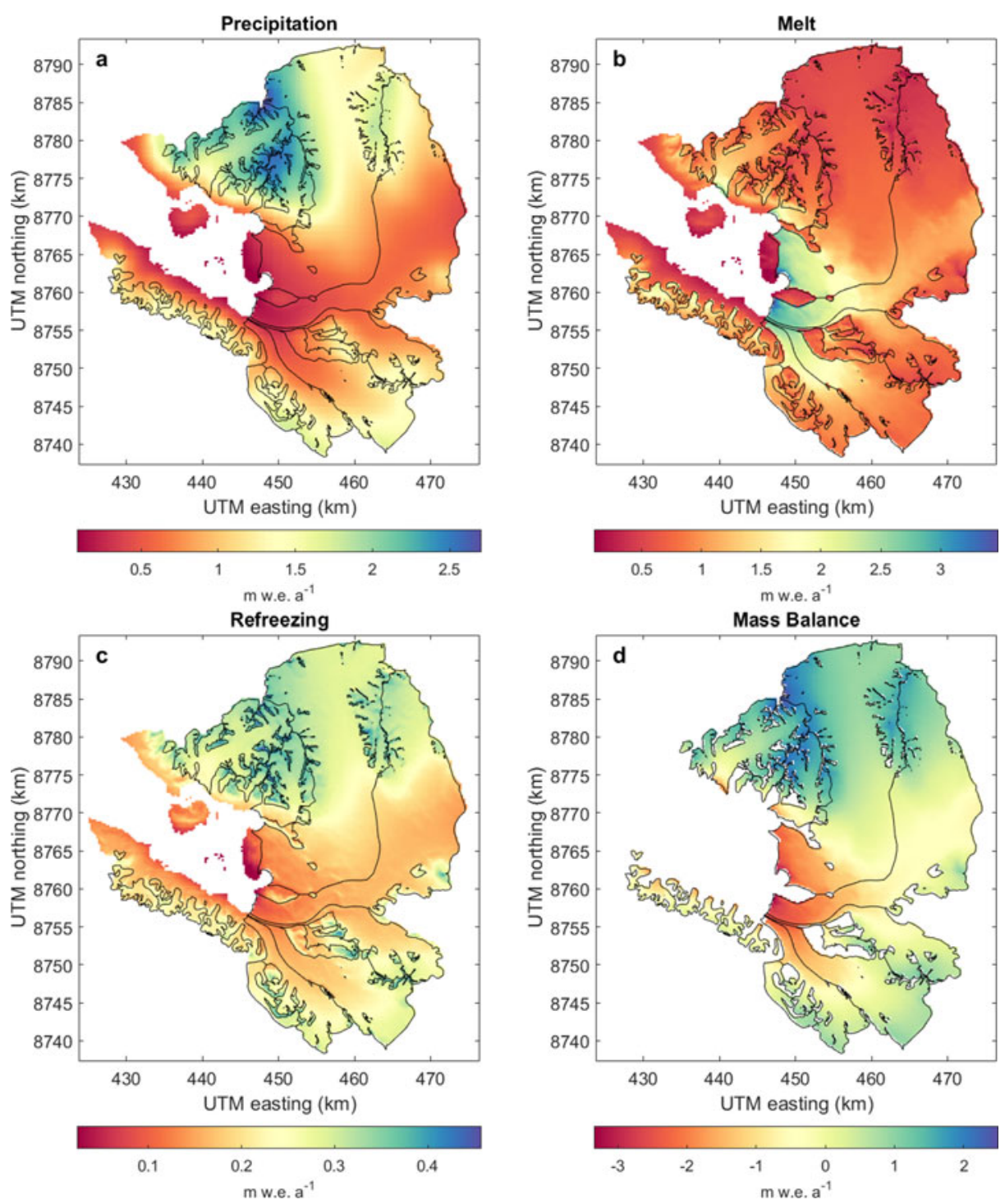

Fig. 5. Long-term spatially distributed pattern of (a) precipitation, (b) melt, (c) refreezing and (d) climatic mass balance averaged over the simulation period 1980-2016. (a-c) are for the entire Kongsfjord basin while (d) shows only the glacierized area.

glacierized basin $\left(+0.0023 \mathrm{~m}\right.$ w.e. $\left.\mathrm{a}^{-2}, p<0.4\right)$ as well as the south $\left(+0.0024\right.$ m w.e. $\left.\mathrm{a}^{-2}, p<0.3\right)$, east $\left(+8.9 \times 10^{-4}\right.$ $\mathrm{m}$ w.e. $\left.\mathrm{a}^{-2}, p<0.7\right)$ and north $\left(+0.0038 \mathrm{~m}\right.$ w.e. $\mathrm{a}^{-2}, p<$ 0.3 ) regions over the simulation period 1980-2016. There is a significant increasing trend in summer temperature, which induces a negative and significant trend in summer balance for the entire glacierized basin as well as in two of the subregions (east and north). However, the summer balance is compensated to a certain extent by the slightly increasing winter precipitation for the entire glacierized area as well as all subregions, thereby yielding a nonsignificant trend in the net climatic mass balance.

\subsection{Runoff}

Figure 8 shows time series of total annual runoff from the glacierized subregions and nonglacierized areas. Runoff from the nonglacierized area is mainly due to snowmelt and comprises $\sim 16 \%$ of the total runoff from the whole basin over the simulation period. Runoff from seasonal snow is limited by the amount of cumulative snowfall in the cold season. Area-averaged runoff from glaciers is largest in the south, followed by the east and north regions
(Table 3). Nevertheless, total glacier runoff is smallest in the south due to the small glacier area; the east region contributes the most fresh water to the fjord (Fig. 8). Differences in runoff between glacierized and nonglacierized areas are largest in years with warm summers due to high rates of glacier ice melt after the disappearance of the seasonal snow.

We find an increasing and statistically significant trend in annual runoff from the glacierized area $\left(6.83 \times 10^{6} \mathrm{~m}^{3} \mathrm{a}^{-1}\right.$ with $p<0.09)$, and the east $\left(3.47 \times 10^{6} \mathrm{~m}^{3} \mathrm{a}^{-1}\right.$ with $p<$ $0.1)$ and north $\left(3.1 \times 10^{6} \mathrm{~m}^{3} \mathrm{a}^{-1}\right.$ with $\left.p<0.08\right)$ regions over the simulation period, while a positive but nonsignificant trend is observed in runoff from the south region $\left(2.51 \times 10^{5}\right.$ $\left.\mathrm{m}^{3} \mathrm{a}^{-1}, p<0.24\right)$. With future warming, runoff from all the glaciers will increase substantially (see section 5.5). Increased runoff volume will potentially lead to more rapid vertical mixing of fresh water at the tidewater glacier front, which would impact the fjord circulation (Sundfjord and others, 2017) and promote more foraging of marine mammals (Lydersen and others, 2014). Increased runoff from land-terminating glaciers would lead to greater stratification and affect the physical and chemical environment of the fjord (Nowak and Hodson, 2013, 2015). 

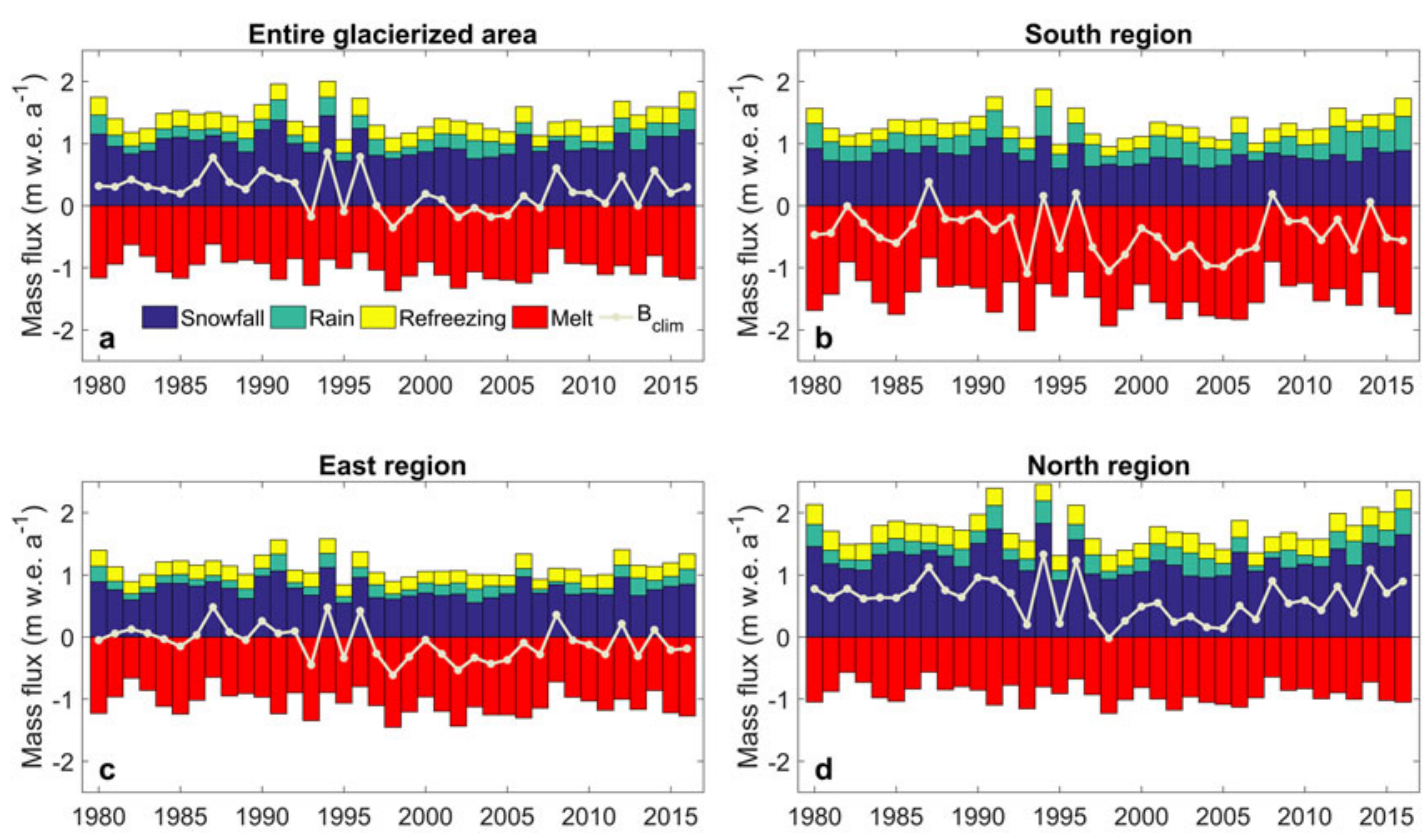

Fig. 6. Glacier area-averaged climatic mass balance and its components over the simulation period 1980-2016 for the (a) entire glacierized area, (b) south region, (c) east region and (d) north region. The climatic mass balance of a year is calculated between 1 September of the previous year and 31 August of the present year.

\subsection{Decadal changes}

Figure 9 shows averages of climatic mass balance, snowfall and rainfall as a function of elevation for the glacierized area of Kongsfjord basin during four periods; 1980-89, 1990-99, 2000-09 and 2010-16 (7 years). The overall positive mass-balance gradient is especially pronounced for the period 2010-16 (Fig. 9a), mainly driven by an increase in snowfall at high elevations (Fig. 9b). On average, mass balance is positive above $600 \mathrm{~m}$ a.s.l., with the major contribution coming from glaciers on the north and northeast side of the fjord. We find substantial increases in precipitation (both snowfall and rainfall) at higher elevations of the basin in the most recent period. However, there is no significant change in snowfall at lower elevations, although rainfall has increased substantially at all elevations. Average rainfall during the last three decades was $0.15 \mathrm{~m}$ w.e. $\mathrm{a}^{-1}$ and has increased by $27 \%$ in 2010-16 compared with 1980-2009. In a warmer and wetter future Svalbard climate (Førland and others, 2011), rainfall is likely to further increase; with most pronounced warming in winter, more rainfall is likely to occur also during the cold season (Van Pelt and others, 2016a).

The mass balance of the entire glacierized area of Kongsfjord has decreased over the last three periods (199099, 2000-09, 2010-16) compared with the 1980-89 period, with 2000-09 having the lowest mass balance $\left(+0.08 \mathrm{~m}\right.$ w.e. $\left.\mathrm{a}^{-1}\right)$ (Fig. 6). Melt and runoff in the 199099 and 2000-09 periods increased substantially compared with the 1980-89 period and decreased in 2010-16. However, melt and runoff in 2010-16 has increased by 12 and $17 \%$, respectively compared with 1980-89 (Fig. 6). The average Equilibrium Line Altitude (ELA) of the glacierized area has increased from $437 \pm 75 \mathrm{~m}$ a.s.l. in 1980-89 to $509 \pm 153 \mathrm{~m}$ a.s.l. and $572 \pm 110 \mathrm{~m}$ a.s.l. in 1990-99 and 2000-09, respectively, decreasing to $517 \pm 74 \mathrm{~m}$ a.s.l. in 2010-16.

\subsection{Subsurface variables}

Figures $10 a, b$ show the time-depth evolution of subsurface density for the period 1990-2015 at two sites; one on a glacier in the south region and the other on a glacier in the north region (locations are shown in Fig. 1). The elevation of both sites is $\sim 610 \mathrm{~m}$ a.s.l., within the accumulation zone of the respective glaciers. In spite of being at similar elevations, we find significant differences in the firn density evolution at these locations. The glacier in the south region has a small accumulation area, and the proximity of the ELA inhibits the formation of a thick firn layer. Firn almost disappears at this location over the period 1998-2006, due to low snowfall and high melting. At a similar elevation in the glacier in the north region, the significantly thicker firn started depleting between 1998 and 2006, caused by low snowfall in this period, when all glaciers show most negative mass balance. The site in the north region is higher above its local ELA than the site in the south, thus leading to the

Table 4. Climatic mass-balance trend of three subregions and entire glacierized area with their corresponding $p$ values

\begin{tabular}{|c|c|c|c|}
\hline Region & Winter Balance $\left(B_{\mathrm{w}}\right)$ & Summer Balance $\left(B_{\mathrm{s}}\right)$ & Annual Balance $\left(B_{\mathrm{n}}\right)$ \\
\hline South & $0.0013(p<0.6)$ & $-0.007(p<0.15)$ & $-0.006(p<0.28)$ \\
\hline East & $0.0001(p<0.9)$ & $-0.0076(p<0.03)$ & $-0.0074(p<0.09)$ \\
\hline North & $0.0028(p<0.4)$ & $-0.0081(p<0.03)$ & $-0.053(p<0.28)$ \\
\hline Entire glacierized area & $0.0014(p<0.6)$ & $-0.0078(p<0.03)$ & $-0.0064(p<0.16)$ \\
\hline
\end{tabular}




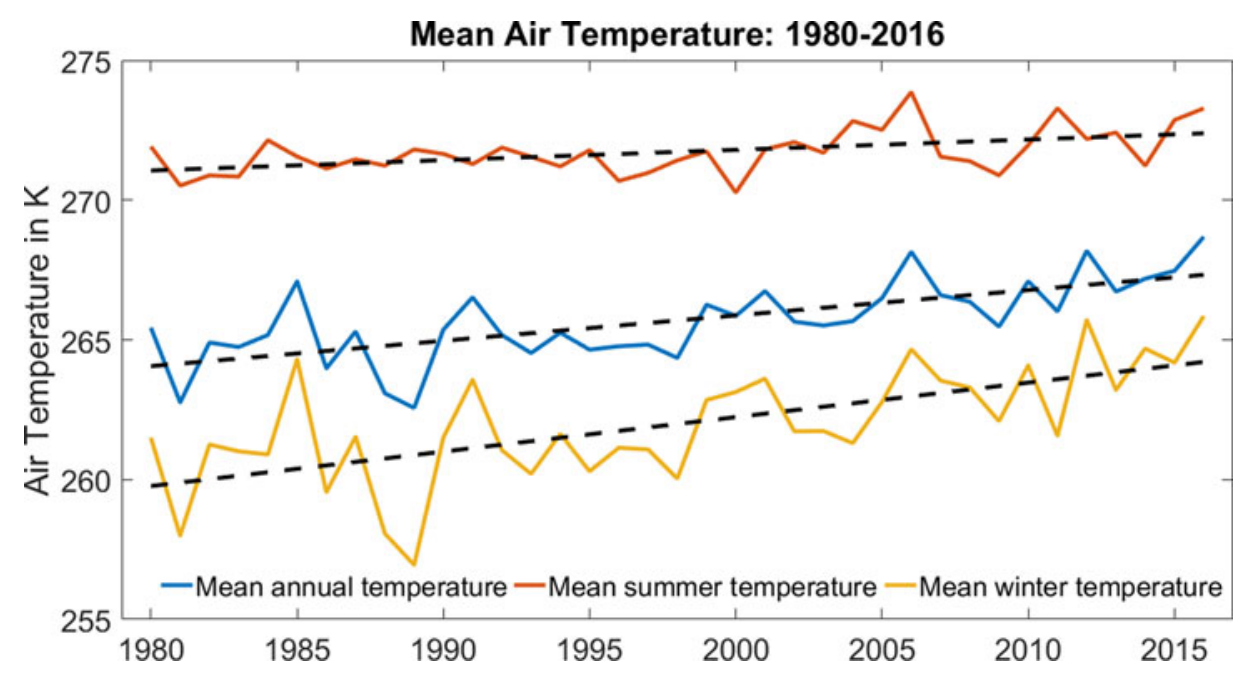

Fig. 7. Temperature (winter, summer and annual) for the period 1980-2016. Mean winter temperature increased around $2 \mathrm{~K}$ between 1980 and 2016. The trends for winter, summer and annual temperature are $0.12 \mathrm{~K} \mathrm{a}^{-1}, 0.03 \mathrm{~K} \mathrm{a}^{-1}$ and $0.09 \mathrm{~K} \mathrm{a}^{-1}$, respectively, shown with black dashed line.

formation of a thicker snow and firn pack. Due to higher snowfall in the post-2006 period, firn thickness starts to increase, especially after 2011, at both locations.

\subsection{Climate sensitivity}

To reduce computational cost, sensitivity tests were conducted at the mass-balance stake locations of the four NPI study glaciers over the period 1979-2016. We performed multiple runs perturbing air temperature $(T)$, precipitation $(P)$ and cloud cover $(C)$ uniformly over the simulation period, without considering any seasonal variability. Table 6 provides the sensitivities of net mass balance, refreezing and runoff to perturbations in $T, P$ and $C$ in terms of anomalies to the long-term mean of the unperturbed state for three glaciers (MLB, KNG and HDF). Altitudinal profiles of sensitivities of mass balance, refreezing and runoff for six changing climate scenarios for $\mathrm{KNG}$ are shown in Figure 11. Mass balance and runoff are generally more sensitive to temperature than precipitation; runoff in the accumulation zone is nearly insensitive to precipitation changes. Refreezing has a complex response to changes in precipitation and temperature (Fig. 11b). Increases in precipitation lead to increased refreezing as a thicker snowpack has a higher cold content and a larger pore volume. This promotes both refreezing of meltwater in the early melt season and refreezing of stored irreducible water after the melt season. Similarly, reduced temperatures will increase snow depth and the extent of the accumulation zone and will simultaneously enhance winter cooling, all of which contribute

Table 5. Correlation between winter snowfall and $\mathrm{CMB}$ and temperature and $\mathrm{CMB}$ for three subregions and entire glacierized area

\begin{tabular}{lcc}
\hline Region & $\begin{array}{c}\text { Winter snowfall-CMB } \\
\text { correlation }\end{array}$ & $\begin{array}{c}\text { Temperature-CMB } \\
\text { correlation }\end{array}$ \\
\hline South & $+0.63(p<0.01)$ & $-0.42(p<0.01)$ \\
East & $+0.68(p<0.01)$ & $-0.37(p<0.03)$ \\
North & $+0.85(p<0.01)$ & $-0.24(p<0.15)$ \\
Entire glacierized & $+0.77(p<0.01)$ & $-0.32(p<0.06)$ \\
$\quad$ area & & \\
& &
\end{tabular}

to enhance refreezing. With the upward migration of the ELA in a warming climate refreezing rates drop and runoff amplifies. This explains the strong nonlinearity in the mass balance and runoff sensitivity to temperature change at sites just above the present ELA (Fig. 11). Table 6 shows that an increase in cloud cover increases runoff and decreases refreezing substantially.

\subsection{Uncertainties}

A substantial source of uncertainty in the presented results comes from the small-scale variability of spatial snow distribution that is not accounted for by the orographic precipitation model. Local topography, wind speed and direction influence snow deposition and distribution in mountainous terrain like Kongsfjord basin (Hodgkins and others, 2005; Lehning and others, 2008; Dadic and others, 2010). Ignoring the small-scale variability of accumulation leads to biases in the area-averaged mass balance as the mass balance has a nonlinear response to snow accumulation (Van Pelt and others, 2014). Another source of uncertainty is that we used a fixed topography and ice extent throughout the entire simulation, which adds uncertainty to the extrapolation of elevation-dependent meteorological parameters, such as temperature and precipitation, and to runoff due to glacier length fluctuations. A $250 \mathrm{~m} \times 250 \mathrm{~m}$ DEM would not properly resolve the topography around smaller glaciers leading to inappropriate shading, which would lead to uncertainty in radiation budget for those glaciers.

We used fixed start and end dates to calculate the mass balance of each year. Although in a warming climate the mass-balance year may need to be redefined eventually, it is convenient for comparison and to detect trends to have fixed dates define the mass-balance year.

Extrapolation of stake data to a glacier-wide grid also leads to uncertainty. In particular, the extrapolation of winter balance may contain significant uncertainty due to potential snow accumulation variability in our study region.

We used a fixed time-invariant TLR for different glaciers over the simulation period which is another source of uncertainty in the model, as cloud condition substantially affects the TLR (Petersen and others, 2013; Matuszko and Weglarczyk, 2014; Van Tricht and others, 2016). 


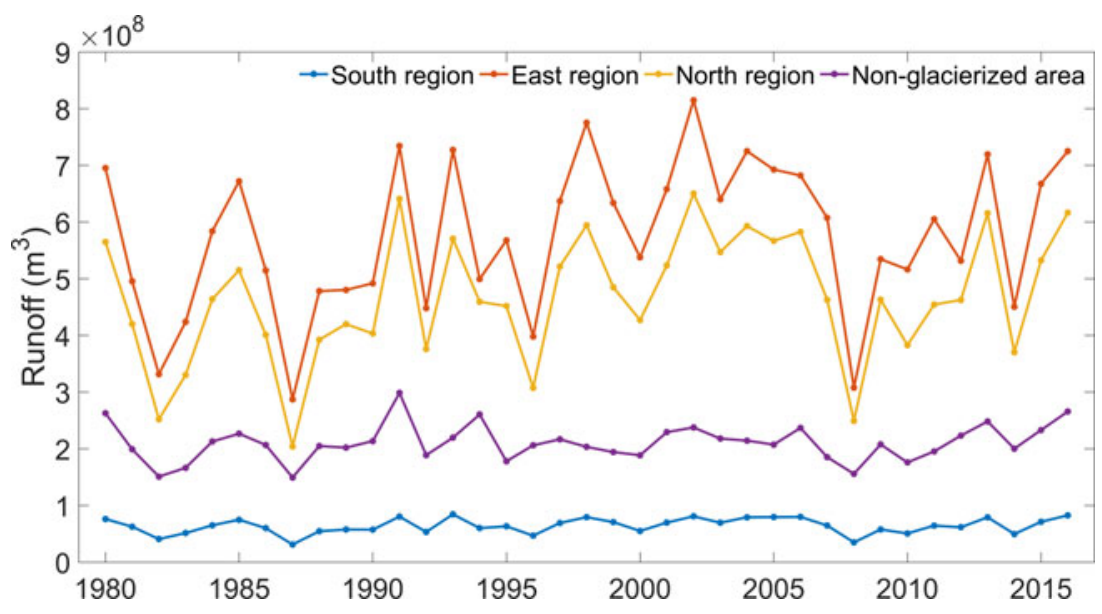

Fig. 8. Total annual runoff from the glacierized and non-glacierized areas over the simulation period 1980-2016. Total runoff from nonglacierized area contributes $16 \%$ of the total freshwater to the fjord. Runoff from seasonal snow is limited by the winter snowfall whereas runoff from the glacierized area is from both snow and ice melt from glaciers.
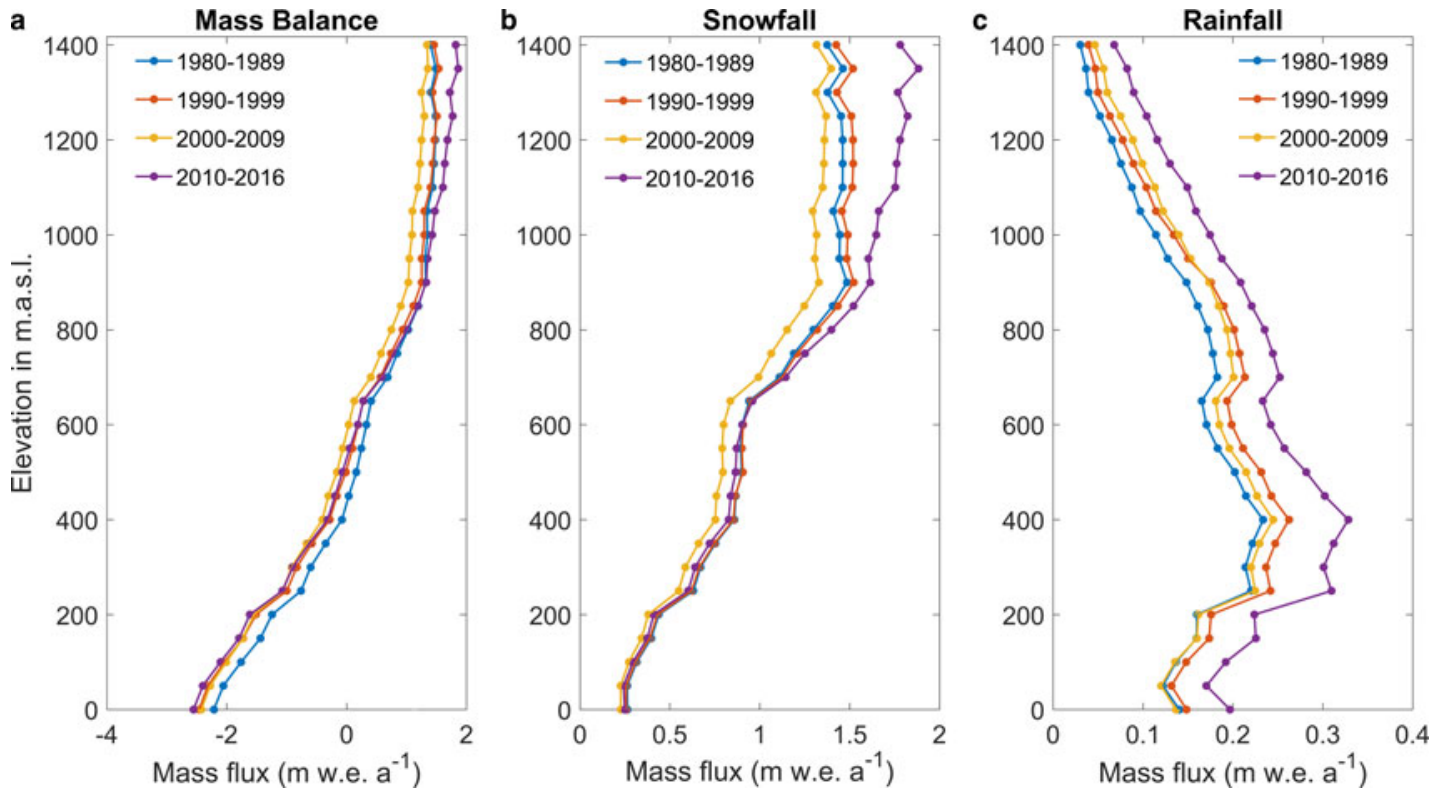

Fig. 9. Evolution of (a) climatic mass balance, (b) snowfall and (c) rainfall for four different periods as a function of elevations. CMB, snowfall and rainfall are averaged over the periods and spatially integrated within $50 \mathrm{~m}$ elevation bins for the glacierized area of the whole Kongsfjord basin.
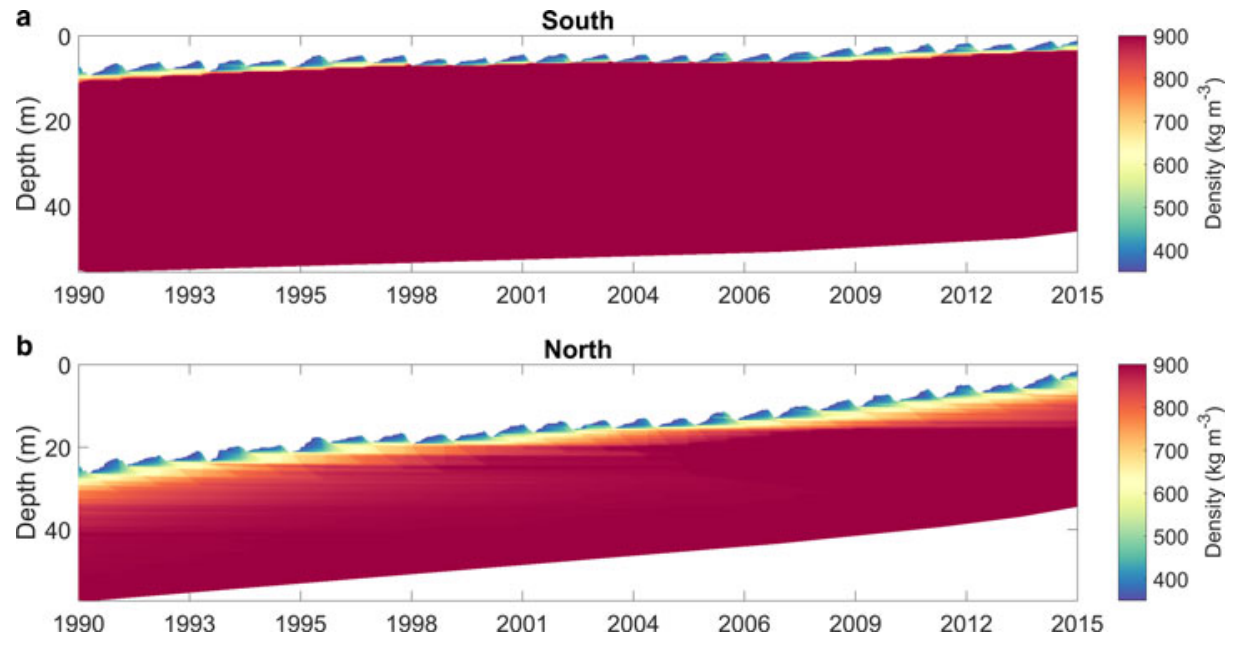

Fig. 10. Time series of simulated subsurface density at a location in the accumulation area of (a) a glacier in the south region and (b) a glacier in the north region. Locations are shown in Fig. 1; both are at an elevation of $610 \mathrm{~m}$ a.s.l. 
Table 6. Overview of mass-balance sensitivity $(\delta B)$, refreezing sensitivity $(\delta R E)$ and runoff sensitivity $(\delta R U)$ to changing temperature $(T)$, precipitation $(P)$ and cloud cover $(C)$ of three glaciers along their central line. Units are in $\mathrm{m}$ w.e. $\mathrm{a}^{-1}$.

\begin{tabular}{|c|c|c|c|c|c|c|c|c|c|}
\hline \multirow[b]{2}{*}{ Run } & \multicolumn{3}{|c|}{ MLB } & \multicolumn{3}{|c|}{ KNG } & \multicolumn{3}{|c|}{ HDF } \\
\hline & $\delta \mathrm{B}$ & $\delta R E$ & $\delta R U$ & $\delta \mathrm{B}$ & $\delta R E$ & $\delta R U$ & $\delta B$ & $\delta R E$ & $\delta R U$ \\
\hline $\mathrm{T}+3 \mathrm{~K}$ & -2.72 & 0.051 & 2.79 & -2.41 & 0.028 & 2.46 & -1.9 & -0.011 & 1.93 \\
\hline $\mathrm{T}+2 \mathrm{~K}$ & -1.73 & 0.039 & 1.77 & -1.50 & 0.015 & 1.53 & -1.16 & -0.019 & 1.18 \\
\hline $\mathrm{T}+1 \mathrm{~K}$ & -0.83 & 0.018 & 0.85 & -0.69 & 0.003 & 0.71 & -0.55 & -0.014 & 0.55 \\
\hline $\mathrm{T}-1 \mathrm{~K}$ & 0.70 & 0.014 & -0.71 & 0.56 & 0.022 & -0.57 & 0.41 & 0.032 & -0.42 \\
\hline $\mathrm{T}-2 \mathrm{~K}$ & 1.18 & 0.049 & -1.20 & 0.99 & 0.054 & -1.01 & 0.61 & 0.043 & -0.62 \\
\hline $\mathrm{T}-3 \mathrm{~K}$ & 1.51 & 0.087 & -1.53 & 1.29 & 0.071 & -1.31 & 0.70 & 0.002 & -0.71 \\
\hline$P+30 \%$ & 0.36 & 0.034 & -0.02 & 0.33 & 0.032 & -0.06 & 0.36 & 0.033 & -0.10 \\
\hline$P+20 \%$ & 0.25 & 0.024 & -0.02 & 0.23 & 0.023 & -0.05 & 0.25 & 0.023 & -0.07 \\
\hline$P+10 \%$ & 0.13 & 0.013 & -0.02 & 0.12 & 0.015 & -0.03 & 0.13 & 0.013 & -0.04 \\
\hline$P-10 \%$ & -0.12 & -0.009 & 0.01 & -0.12 & -0.007 & 0.04 & -0.13 & -0.006 & 0.04 \\
\hline $\mathrm{P}-20 \%$ & -0.28 & -0.02 & 0.05 & -0.26 & -0.019 & 0.08 & -0.26 & -0.016 & 0.09 \\
\hline $\mathrm{P}-30 \%$ & -0.45 & -0.031 & 0.11 & -0.40 & -0.031 & 0.14 & -0.40 & -0.027 & 0.14 \\
\hline$C+15 \%$ & -0.16 & -0.007 & 0.15 & -0.13 & -0.006 & 0.12 & -0.11 & -0.011 & 0.1 \\
\hline$C+10 \%$ & -0.12 & -0.004 & 0.12 & -0.09 & -0.002 & 0.09 & -0.07 & -0.006 & 0.07 \\
\hline$C+5 \%$ & -0.07 & -0.002 & 0.07 & -0.05 & 0.002 & 0.05 & -0.03 & -0.001 & 0.03 \\
\hline$C-5 \%$ & 0.2 & 0.006 & -0.19 & 0.18 & 0.011 & -0.17 & 0.19 & 0.016 & -0.19 \\
\hline$C-10 \%$ & 0.36 & 0.014 & -0.34 & 0.33 & 0.019 & -0.31 & 0.33 & 0.027 & -0.31 \\
\hline$C-15 \%$ & 0.48 & 0.023 & -0.46 & 0.45 & 0.028 & -0.43 & 0.42 & 0.037 & -0.4 \\
\hline
\end{tabular}

Sensitivity values of BRB are similar to MLB and therefore not shown here.
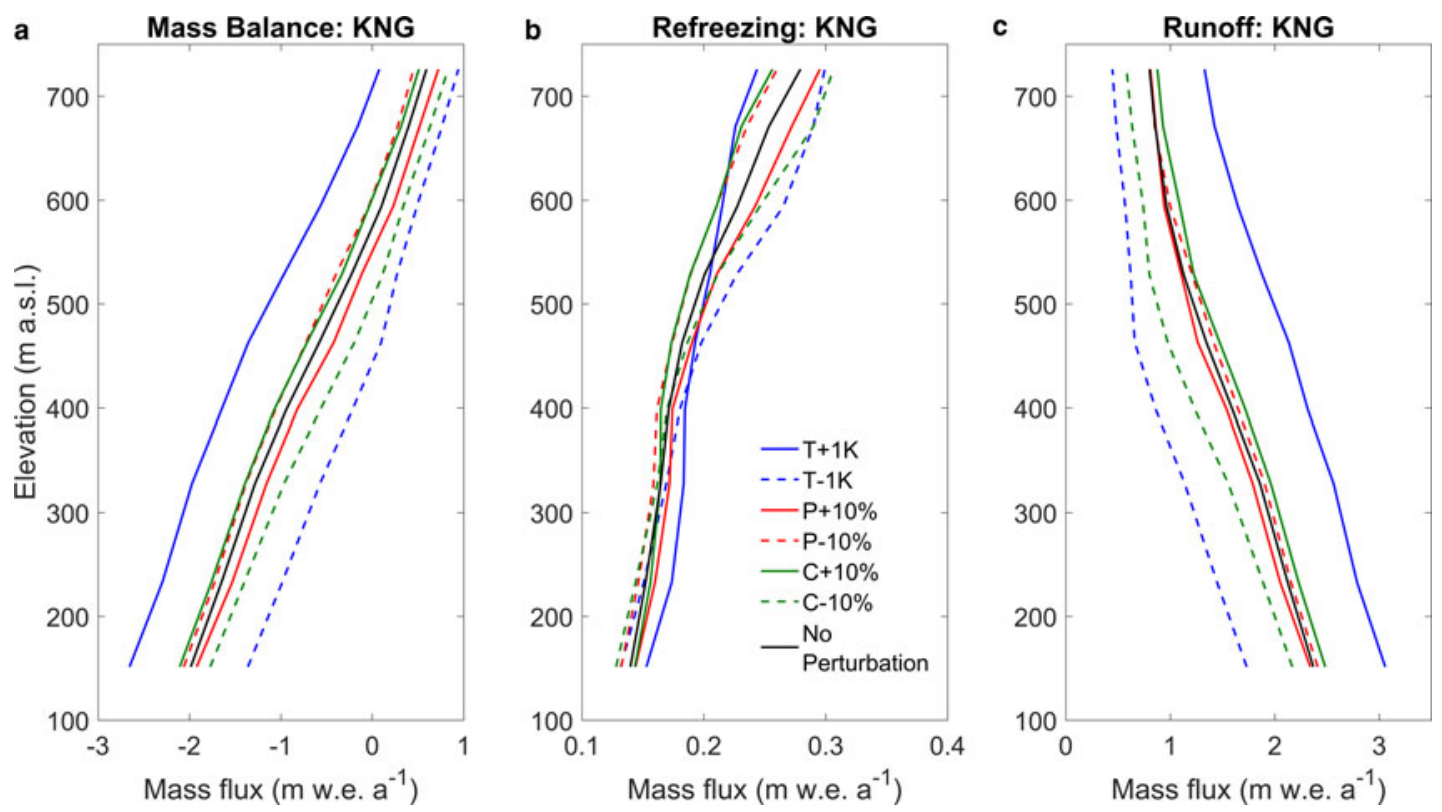

Fig. 11. Sensitivities to perturbations in temperature $(T)$, precipitation $(P)$ and cloud cover $(C)$ of (a) mass balance, (b) refreezing and (c) runoff along the centreline of Kongsvegen (KNG).

Finally, observations used for model calibration and validation do not include any glaciers in the north region, which increases the uncertainty of the results in this region. More observational data from this region will help to constrain uncertainties.

\section{CONCLUSIONS}

We use a surface energy-balance model coupled with a subsurface snow/firn model (Van Pelt and others, 2012) to simulate the long-term (1980-2016) evolution of the CMB of glaciers and the associated fresh water flux into the Kongsfjord basin. The model is forced with downscaled ERA-Interim precipitation and climate data extrapolated from the nearby meteorological station in Ny-Ålesund, on a $250 \mathrm{~m} \times 250 \mathrm{~m}$ grid. Calibration is performed by adjusting the TLR to match the measured summer balance data.

Results indicate that glaciers of Kongsfjord basin show wide variability in mass balance from south to north and from west to east. The CMB of the entire Kongsfjord basin is estimated to an average of $+0.23 \mathrm{~m}$ w.e. $\mathrm{a}^{-1}$ over the simulation period. Glaciers in the north region of Kongsfjord show overall positive $\mathrm{CMB}$ and are least sensitive to temperature perturbations, whereas glaciers in the south and east regions show overall negative $\mathrm{CMB}$ and are more sensitive. The net $\mathrm{CMB}$ of the entire glacierized basin shows a weakly negative but nonsignificant trend, although summer balance has a negative and significant trend over the simulation period 1980-2016. 
Comparison of mass-balance components during the periods 1980-89, 1990-99, 2000-09 and 2010-16 shows a lowest CMB (+0.08 $\mathrm{m}$ w.e. $\left.\mathrm{a}^{-1}\right)$ in the 2000-09 period. The most recent period (2010-16) had above-average precipitation, which could be related to recent retreat of Arctic sea-ice cover and increasing winter temperatures. Increase in snowfall is observed only at higher elevation but rainfall increases throughout the domain.

Refreezing accounts for $17 \%$ of the total mass gain and is higher in the north $\left(0.27 \mathrm{~m}\right.$ w.e. $\left.\mathrm{a}^{-1}\right)$ than in the south $(0.21$ $\mathrm{m}$ w.e. $\left.\mathrm{a}^{-1}\right)$. Snowmelt from nonglacierized areas in early summer contributes $16 \%$ of the total runoff to the fjord, while the remaining $84 \%$ is from glacier runoff. The largest contribution to total runoff comes from the east region. We find a significant increase in runoff trend over the simulation period from the entire glacierized area.

\section{ACKNOWLEDGEMENTS}

The first author received Ph.D. studentship support from ESSO-National Centre for Antarctic and Ocean Research (NCAOR), financed by the Ministry of Earth Sciences, Government of India; Grant/Award number: MoES/16/22/ 12-RDEAS (PhD fellowship-NPI). Additional funding came from the Polish-Norwegian Research Programme GLAERE, the Norwegian Research Council project TIGRIF, and the Norwegian Polar Institute's TW-ICE project. We thank the editor, $H$. Jiskoot and one anonymous referee for their insightful comments that helped to improve the manuscript. This article is NCAOR contribution no. 46/2018.

\section{REFERENCES}

Aas KS and 6 others (2016) The climatic mass balance of Svalbard glaciers: a 10-year simulation with a coupled atmosphereglacier mass balance model. Cryosphere, 10(3), 1089-1104

Arnold NS, Rees WG, Hodson AJ and Kohler J (2006) Topographic controls on the surface energy balance of a high Arctic valley glacier. J. Geophys. Res., 111(F2), F02011 (doi: 10.1029/ 2005jf000426)

Bliss A, Hock R and Radić V (2014) Global response of glacier runoff to twenty-first century climate change. J. Geophys. Res.- Earth Surf., 119(4), 717-730

Bring A and 9 others (2016) Arctic terrestrial hydrology: a synthesis of processes, regional effects, and research challenges. J. Geophys. Res.: Biogeo., 121(3), 621-649

Bruland O and Hagen JO (2002) Glacial mass balance of Austre Brøggerbreen (Spitsbergen), 1971-1999, modelled with a precipitation-run-off model. Polar Res., 21(1), 109-121

Burton DJ, Dowdeswell JA, Hogan KA and Noormets R (2016) Marginal fluctuations of a Svalbard surge-type tidewater glacier, Blomstrandbreen, since the Little Ice Age: a record of three surges. Arct. Antarct. Alp. Res., 48(2), 411-426

Church JA and 9 others (2011) Revisiting the Earth's sea-level and energy budgets from 1961 to 2008. Geophys. Res. Lett., 38 (18), L18601 (doi: 10.1029/2011gl048794)

Cowton T, Slater D, Sole A, Goldberg D and Nienow P (2015) Modeling the impact of glacial runoff on fjord circulation and submarine melt rate using a new subgrid-scale parameterization for glacial plumes. J. Geophys. Res.- Oceans, 120(2), 796-812

Dadic R, Mott R, Lehning M and Burlando P (2010) Wind influence on snow depth distribution and accumulation over glaciers. J. Geophys. Res.- Earth Surf., 115, F01012 (doi: 10.1029/ 2009jf001261)

Dee DP and 35 others (2011) The ERA-interim reanalysis: configuration and performance of the data assimilation system. Q. J. Roy. Meteor. Soc., 137(656), 553-597
Duethmann D and 9 others (2015) Attribution of streamflow trends in snow and glacier melt-dominated catchments of the Tarim river, Central Asia. Water Resour. Res., 51(6), 4727-4750

Førland EJ and Hanssen-Bauer I (2000) Increased precipitation in the Norwegian Arctic: true or false? Climate Change, 46(4), 485-509

Førland EJ, Benestad R, Hanssen-Bauer I, Haugen JE and Skaugen TE (2011) Temperature and precipitation development at Svalbard 1900-2100. Adv. Meteorol., 2011, 893790 (doi: 10.1155/2011/ 893790)

Greuell W and Konzelmann T (1994) Numerical modelling of the energy-balance and the englacial temperature of the Greenland ice-sheet- calculations for the ETH-camp location (West Greenland, 1155 masl). Global Planet. Change, 9(1-2), 91-114

Hagen JO, Liestøl O, Roland E and Jørgensen T (1993). Glacier atlas of Svalbard and Jan Mayen. Norsk Polarinstitutt, Oslo.

Hagen JO, Melvold K, Eiken T, Isaksson E and Lefauconnier B (1999) Mass balance methods on Kongsvegen, Svalbard. Geogr. Ann. A., 81A(4), 593-601

Hagen JO, Kohler J, Melvold K and Winther JG (2003) Glaciers in Svalbard: mass balance, runoff and freshwater flux. Polar Res., 22(2), 145-159

Hansen BB and 8 others (2014) Warmer and wetter winters: characteristics and implications of an extreme weather event in the high Arctic. Environ. Res. Lett., 9(11), 114021 (doi: 10.1088/17489326/9/11/114021)

Hock R (2003) Temperature index melt modelling in mountain areas. J. Hydro., 282(1-4), 104-115

Hock R (2005) Glacier melt: a review of processes and their modelling. Prog. Phys. Geog., 29(3), 362-391

Hodgkins R, Cooper R, Wadham J and Tranter M (2005). Interannual variability in the spatial distribution of winter accumulation at a high-Arctic glacier (Finsterwalderbreen, Svalbard), and its relationship with topography. Ann. Glaciol 42, 243-248

How P and 9 others (2017) Rapidly changing subglacial hydrological pathways at a tidewater glacier revealed through simultaneous observations of water pressure, supraglacial lakes, meltwater plumes and surface velocities. Cryosphere, 11 (6), 2691-2710

Huss M and Farinotti D (2012) Distributed ice thickness and volume of all glaciers around the globe. J. Geophys. Res.- Earth Surf., 117, F04010 (doi: 10.1029/2012jf002523)

IPCC (2013). Summary for Policymakers. In Stocker TF, Qin D, Plattner G-K, Tignor M, Allen SK, Boschung J, Nauels A, Xia Y, Bex V and Midgley PM, eds. Climate Change 2013: The Physical Science Basis. Contribution of Working Group I to the Fifth Assessment Report of the Intergovernmental Panel on Climate Change. Cambridge, United Kingdom and New York, NY, USA. 9-23

Jacob T, Wahr J, Pfeffer WT and Swenson S (2012) Recent contributions of glaciers and ice caps to sea level rise. Nature, 482(7386), 514-518

Jeelani G, Feddema JJ, van der Veen CJ and Stearns L (2012) Role of snow and glacier melt in controlling river hydrology in Liddar watershed (western Himalaya) under current and future climate. Water Resour. Res., 48, W12508 (doi: 10.1029/ 2011wr011590)

Kääb A, Lefauconnier B and Melvold K (2005) Flow field of Kronebreen, Svalbard, using repeated Landsat 7 and ASTER data. Ann. Glaciol., 42, 7-13

Kohler J (2013) Mass balance for glaciers near Ny-Ålesund [Data set] Norwegian Polar Institute. (doi: 10.21334/npolar.2013.ad6c4c5a)

Kohler J and Aanes R (2004) Effect of winter snow and ground-icing on a Svalbard reindeer population: results of a simple snowpack model. Arct. Antarct. Alp. Res., 36(3), 333-341

Kohler J and 7 others (2007) Acceleration in thinning rate on western Svalbard glaciers. Geophys. Res. Lett., 34(18), L18502 (doi: 10.1029/2007gl030681)

Kohler J, König M, Nuth C and Villaflor G (2018). Svalbard tidewater glacier front database [Data set] Norwegian Polar Institute. (doi: 10.21334/npolar.2018. 7cd67b1a) 
König M, Nuth C, Kohler J, Moholdt G and Pettersen R (2014). Global land Ice measurements from space, Springer, Berlin, Heidelberg.

Lefauconnier B and Hagen JO (1990) Glaciers and Climate in Svalbard: Statistical Analysis and Reconstruction of the Brøggerbreen Mass Balance for the Last 77 Years. Ann. Glaciol., 14, 148-152

Lefauconnier B, Hagen JO, Pinglot JF and Pourchet M (1994a) Mass balance estimates on the glacier complex Kongsvegen and Sveabreen, Spitsbergen, Svalbard, using radioactive layers J. Glaciol., 40(135), 368-376

Lefauconnier B, Hagen JO and Rudant JP (1994b) Flow speed and calving rate of Kongsbreen glacier, Svalbard, using SPOT images. Polar Res., 13(1), 59-65

Lehning M, Löwe H, Ryser M and Raderschall N (2008) Inhomogeneous precipitation distribution and snow transport in steep terrain. Water Resour. Res., 44(7), W07404 (doi: 10.1029/ 2007wr006545)

Liestøl O (1988) The glaciers in the Kongsfjorden area, Spitsbergen. Norsk Geogr. Tidsskr., 42 (4), 231-238

Lydersen C and 12 others (2014) The importance of tidewater glaciers for marine mammals and seabirds in Svalbard, Norway. J. Marine Syst., 129, 452-471

Machguth $\mathrm{H}$ and 8 others (2013) The future sea-level rise contribution of Greenland's glaciers and ice caps. Environ. Res. Lett., 8(2), 025005 (doi: 10.1088/1748-9326/8/2/025005)

Manabe S and Stouffer RJ (1980) Sensitivity of a global climate model to an increase of $\mathrm{CO}_{2}$ concentration in the atmosphere. J. Geophys. Res.- Oceans, 85(C10), 5529-5554

Mansell D, Luckman A and Murray T (2012) Dynamics of tidewater surge-type glaciers in northwest Svalbard. J. Glaciol., 58(207), 110-118

Martín-Español A, Navarro FJ, Otero J, Lapazaran JJ and Błaszczyk M (2015) Estimate of the total volume of Svalbard glaciers, and their potential contribution to sea-level rise, using new regionally based scaling relationships. J. Glaciol., 61(225), 29-41

Matuszko D and Weglarczyk S (2014) Effect of cloudiness on longterm variability in air temperature in Krakow. Int. J. Climatol., 34 (1), 145-154

Meier MF and 7 others (2007) Glaciers dominate eustatic sea-level rise in the 21st century. Science, 317(5841), 1064-1067

Mernild SH, Liston GE and Hiemstra CA (2014) Northern hemisphere glacier and ice cap surface mass balance and contribution to sea level rise. J. Climate, 27(15), 6051-6073

Mernild SH and 5 others (2016) The Andes Cordillera. Part IV: spatio-temporal freshwater run-off distribution to adjacent seas (1979-2014). Int. J. Climatol., 37, 3175-3196 (doi: 10.1002/ joc.4922)

Moon T, Ahlstrøm A, Goelzer H, Lipscomb W and Nowicki S (2018) Rising oceans guaranteed: arctic land ice loss and sea level rise. Curr. Clim. Change Rep., 4(3), 211-222

Nordli $\varnothing$, Przybylak R, Ogilvie AEJ and Isaksen K (2014) Longterm temperature trends and variability on Spitsbergen: the extended Svalbard Airport temperature series, 1898-2012. Polar Res. 33, 21349 (doi: 10.3402/polar.v33.21349)

Norwegian Polar Institute (NPI) (2014). Terrengmodell Svalbard (SO Terrengmodell) [data set]. Norwegian Polar Institute. (doi 10.21334/npolar.2014.dce53a47)

Nowak A and Hodson A (2013) Hydrological response of a high-Arctic catchment to changing climate over the past 35 years: a case study of Bayelva watershed, Svalbard. Polar Res., 32(1), 19691

Nowak A and Hodson A (2015) On the biogeochemical response of a glacierized high Arctic watershed to climate change: revealing patterns, processes and heterogeneity among micro-catchments. Hydrol. Process., 29(6), 1588-1603

Nuth C, Schuler TV, Kohler J, Altena B and Hagen JO (2012) Estimating the long-term calving flux of kronebreen, Svalbard, from geodetic elevation changes and mass-balance modelling. J. Glaciol., 58(207), 119-133
Nuth C and 7 others (2013) Decadal changes from a multi-temporal glacier inventory of Svalbard. Cryosphere, 7(5), 1603-1621

Østby TI, Schuler TV, Hagen JO, Hock R and Reijmer LH (2013) Parameter uncertainty, refreezing and surface energy balance modelling at Austfonna ice cap, Svalbard, 2004-08. Ann. Glaciol., 54(63), 229-240

Østby TI and 5 others (2017) Diagnosing the decline in climatic mass balance of glaciers in Svalbard over 1957-2014. Cryosphere, 11(1), 191-215

Petersen L, Pellicciotti F, Juszak I, Carenzo M and Brock B (2013) Suitability of a constant air temperature lapse rate over an Alpine glacier: testing the Greuell and Böhm model as an alternative. Ann. Glaciol., 54(63), 120-130

Pfeffer WT and 76 others (2014) The Randolph Glacier Inventory: a globally complete inventory of glaciers. J. Glaciol., 60(221), 537-552

Poinar K, Joughin I, Lenaerts JTM and van den Broeke MR (2017) Englacial latent-heat transfer has limited influence on seaward ice flux in western Greenland. J. Glaciol., 63(237), 1-16

Radić V and Hock R (2010) Regional and global volumes of glaciers derived from statistical upscaling of glacier inventory data. J. Geophys. Res.- Earth Surf., 115, F01010 (doi: 10.1029/ 2009jf001373)

Radić V and Hock R (2011) Regionally differentiated contribution of mountain glaciers and ice caps to future sea-level rise. Nat. Geosci., 4(2), 91-94

Rasmussen LA and Kohler J (2007) Mass balance of three Svalbard glaciers reconstructed back to 1948. Polar Res., 26(2), 168-174

Reijmer CH and Hock R (2008) Internal accumulation on Storglaciären, Sweden, in a multi-layer snow model coupled to a distributed energy- and mass-balance model. J. Glaciol., 54 (184), 61-72

Reijmer CH, van den Broeke MR, Fettweis X, Ettema J and Stap LB (2012) Refreezing on the Greenland ice sheet: a comparison of parameterizations. Cryosphere, 6(4), 743-762

Rippin D and 6 others (2003) Changes in geometry and subglacial drainage of Midre Lovénbreen, Svalbard, determined from digital elevation models. Earth Surf. Proc. Land., 28(3), 273-298

Schellenberger T, Dunse T, Kääb A, Kohler J and Reijmer CH (2015) Surface speed and frontal ablation of Kronebreen and Kongsbreen, NW Svalbard, from SAR offset tracking. Cryosphere, 9(6), 2339_ 2355

Schneider T and Jansson P (2004) Internal accumulation in firn and its significance for the mass balance of Storglaciären, Sweden. J. Glaciol., 50(168), 25-34

Serreze MC and Francis JA (2006) The Arctic amplification debate. Climate Change, 76(3-4), 241-264

Serreze MC, Barrett AP, Stroeve JC, Kindig DN and Holland MM (2009) The emergence of surface-based Arctic amplification. Cryosphere, 3(1), 11-19

Smith RB and Barstad I (2004) A linear theory of orographic precipitation. J. Atmos. Sci., 61(12), 1377-1391

Sund $M$ and Eiken T (2010) Recent surges on Blomstrandbreen, Comfortlessbreen and Nathorstbreen, Svalbard. J. Glaciol., $\mathbf{5 6}$ (195), 182-184

Sundfjord A and 11 others (2017) Effects of glacier runoff and wind on surface layer dynamics and Atlantic Water exchange in Kongsfjorden, Svalbard; a model study. Estuar. Coast. Shelf. S., 187, 260-272

Valentin MM, Hogue TS and Hay LE (2018) Hydrologic regime changes in a high-latitude glacierized watershed under future climate conditions. Water. (Basel), 10(2), 128 (doi: 10.3390/w10020128)

Van Pelt W and Kohler J (2015) Modelling the long-term mass balance and firn evolution of glaciers around Kongsfjorden, Svalbard. J. Glaciol., 61(228), 731-744

Van Pelt WJJ and 5 others (2012) Simulating melt, runoff and refreezing on Nordenskiöldbreen, Svalbard, using a coupled snow and energy balance model. Cryosphere, 6(3), 641-659

Van Pelt WJJ and 5 others (2014) Inverse estimation of snow accumulation along a radar transect on Nordenskiöldbreen, Svalbard. J. Geophys. Res.- Earth Surf., 119(4), 816-835 
Van Pelt WJJ and 6 others (2016a) Multidecadal climate and seasonal snow conditions in Svalbard. J. Geophys. Res.- Earth Surf., 121(11), 2100-2117

Van Pelt WJJ, Pohjola VA and Reijmer CH (2016b) The changing impact of snow conditions and refreezing on the mass balance of an idealized Svalbard Glacier. Front. Earth. Sci. 4, 102 (doi: 10.3389/feart.2016.00102)

Van Tricht K and 8 others (2016) Clouds enhance Greenland ice sheet meltwater runoff. Nat. Commun. 7, 10266 (doi: 10.1038/ ncomms10266)

Verbunt $M$ and 5 others (2003) The hydrological role of snow and glaciers in alpine river basins and their distributed modeling. J. Hydro., 282(1-4), 36-55
Westermann S, Boike J, Langer M, Schuler TV and Etzelmüller B (2011) Modeling the impact of wintertime rain events on the thermal regime of permafrost. Cryosphere, 5(4), 945-959

World Glacier Monitoring Service (WGMS) (2017). Global glacier change bulletin No. 2 (2014-2015). In Zemp M, Nussbaumer SU, Gärtner-Roer I, Huber J, Machguth H, Paul F and Hoelzle M, eds. ICSU(WDS)/IUGG(IACS)/UNEP/ UNESCO/WMO, World Glacier Monitoring Service, Zurich, Switzerland, 28-29, 244 pp., (doi: 10.5904/wgms-fog-2017-10).

Wright AP and 5 others (2007) Modeling the refreezing of meltwater as superimposed ice on a high Arctic glacier: a comparison of approaches. J. Geophys. Res., 112(F4) (doi: 10.1029/2007jf0 00818)

MS received 3 June 2018 and accepted in revised form 25 September 2018; first published online 31 October 2018 